\title{
Invenção da segurança escolar: policiamento em duas escolas do município de Hortolândia - SP
}

\section{David Rodrigues Menezes (IC)}

\begin{abstract}
Resumo
Este trabalho de pesquisa busca desenvolver uma análise comparativa entre os regimes de segurança adotado por duas escolas de nível médio no município de Hortolândia - SP, sendo uma da rede pública estadual de ensino, e a outra da rede privada. O objetivo desta investigação é analisar as questões que dizem respeito à "invenção da segurança" no ambiente escolar, tendo a interação e as relações mantidas entre o público escolar e os agentes responsáveis por realizar a segurança como foco central da análise.
\end{abstract}

Palavras Chave: Segurança, Policiamento, Violência Escolar.

\section{Introdução}

No Brasil, a relação entre violência e segurança escolar se tornou um importante objeto de reflexão para pesquisadores, autoridades e instituições, movendo diversos debates. Para Barroso (apud Barros, 2009), a sociedade costuma tratar os casos que envolvem violência escolar de forma distorcida, sem grande rigor analítico. A falta de rigor frente essas questões gera soluções igualmente distorcidas no que tange a segurança. Portanto, é evidente a necessidade da construção de uma visão crítica em relação a este fenômeno, à medida que permeia todas as relações existentes no ambiente, algo já percebido por Abramovay (2002). Este trabalho se propôs a investigar as questões referentes à invenção da segurança escolar, por meio da análise dos regimes de segurança adotados em duas escolas de ensino médio de Hortolândia - SP.

\section{Resultados e Discussão}

As razões que justificam a insegurança de cada comunidade escolar são distintas. $\mathrm{Na}$ escola pública a insegurança é causada por uma série de boatos de que os alunos que residem nas proximidades da escola possuem envolvimento com a criminalidade local. Estes boatos retroalimentam 0 imaginário da comunidade escolar de que a qualquer momento a violência vivida pelos alunos no ambiente externo possa adentrar a escola. No caso da escola privada, o sentimento de insegurança surge a partir da possibilidade de sujeitos estranhos à escola, atraídos pelo alto nível aquisitivo dos estudantes, adentrarem o espaço escolar para cometer crimes - como, por exemplo, roubos e furtos.

\section{Conclusões}

Ambas as escolas operam seus regimes de segurança a partir de tarefas rotineiras e de acordo com as diferentes características do contexto social em que estão inseridas, uma vez que cada escola apresenta uma forma bastante peculiar de realizar o policiamento - o que corrobora com a ideia de Durão e Darck (2012) de que o conceito de segurança varia e define-se conforme os contextos locais. O fenômeno social evidenciado por Fernandes e Rêgo (2011), que o sentimento de insegurança da sociedade aumenta de forma relativamente independente face ao real aumento real da violência também pode ser constatado em ambas as escolas.

\section{Agradecimentos}

Agradeço ao Conselho Nacional de Desenvolvimento Científico e Tecnológico (CNPq), e ao Serviço de Apoio ao Estudante (SAE) da Unicamp por garantirem as condições materiais para que este trabalho fosse desenvolvido. Além disso, à minha mãe, fonte eterna de amor, compreensão e inspiração.

${ }^{1}$ Abramovay, M. Violências nas escolas, 2002, 400

2 APEOESP. O Olhar dos Professores, 2013

${ }^{3}$ Barros, M. N. T. Violência escolar ou escola violenta?, 2009

${ }^{4}$ Charlot, B. A etnografia da escola. Em aberto, 1992, 73 - 86.

${ }^{5}$ Cunha, M. e Durão, S. Os sentidos da segurança: ambiguidades e reduções. Etnográfica, 2011, 53-66.

${ }^{6}$ Durão, S. e Darck, M. (Org.) Polícia, Segurança e Ordem Pública. Perspectivas portuguesas e brasileiras, 2012.

7 Fernandes, L. e Rêgo, X. Por onde anda o sentimento de insegurança? Etnográfica, 2011, 167-181.

${ }^{8}$ Guimarães, Á. M. A dinâmica da violência escolar: conflito e ambiguidade. 1996, $172 \mathrm{p}$

${ }^{9}$ Magnani, J. G. C. Etnografia Como Prática e Experiência. 2009, $129-156$

${ }^{10}$ Muniz, J. e Paes-Machado, E. Polícia para quem precisa de polícia: contribuições aos estudos sobre policiamento. 2010, $437-$ 447.

${ }^{11}$ Rolim, M. A Síndrome da Rainha Vermelha: policiamento $e$ segurança pública no século XXI. 2009.

${ }^{12}$ Weber, M. Ciência e Política. Duas Vocações. 1993.

${ }^{13}$ Willis, P. E. Learning to Labor: How Working Class Kids Get W 